\title{
Inculcation of Science Process Skills in a Science Classroom
}

\author{
Rose Amnah Abd Rauf ${ }^{1}$, Mohamad Sattar Rasul ${ }^{2}$, Azlin Norhaini Mansor ${ }^{2}$, Zarina Othman ${ }^{2} \&$ N. Lyndon ${ }^{3}$ \\ ${ }^{1}$ Faculty of Education, Universiti Malaya (UM), Malaysia \\ ${ }^{2}$ Faculty of Education, Universiti Kebangsaan Malaysia (UKM), Malaysia \\ ${ }^{3}$ School of Social Development and Environmental Studies, Faculty of Humanities and Social Sciences, \\ Universiti Kebangsaan Malaysia, Malaysia
}

Correspondence: Rose Amnah Abd Rauf, Faculty of Education, Universiti Malaya (UM), Kuala Lumpur 50603, Malaysia. Tel: 60-3-7967-5198. E-mail: rose_amnah@hotmail.com

\author{
Received: February 12, 2013 Accepted: March 29, 2013 Online Published: April 25, 2013 \\ doi:10.5539/ass.v9n8p47 \\ URL: http://dx.doi.org/10.5539/ass.v9n8p47
}

\begin{abstract}
Teachers play an important role for teaching science process skills in class through planning and arranging learning activities and teaching how to reach scientific information. The purpose of this study was to investigate whether the teaching aproaches used in the teaching and learning process of a science class are able to provide the opportunity to inculcate science process skills and to identify which science process skills were inculcated (if any) during the lesson without actually planning to teach science process skills. This is a qualitative case study in two Smart Schools in Malaysia. 24 students aged 14 years old and two science teachers were the sample of this study This study revealed that the process of teaching and learning science that uses various teaching approaches in one science lessons has additional advantages in terms of providing opportunities for the inculcation of science process skills. It also managed to provide the students with the opportunity to learn independently in acquiring some of the skills. The use of various teaching approaches is in juxtaposition to each other. Science teaching and learning process is a dynamic process, where the movement from one teaching approach to another occur and not necessarily always occur in an orderly sequence. Hence, the use of various teaching approaches in a single lesson can create more opportunities for inculcation and acquisition of science process skills in the classroom.
\end{abstract}

Keywords: science process skills, inculcation, teaching approach

\section{Introduction}

We are in the era of science and technology where scientific knowledge has grown exponentially and technology has progressed at a rapid pace. Its effects can be clearly seen in all aspects of our lives. Science education plays a key role for the futures of societies. Globally, countries have continuously sought to improve the quality of science education particularly developing countries.

As mentioned by Kirscher, Sweller \& Clark (2006), disputes about the impact of instructional guidance during teaching and learning of science have been ongoing for at least the past half-century. Arguments being whether students learn best in an unguided /minimally guided teaching-learning environment or novice learners should be given direct instructional guidance on the concepts and procedures. Both arguments have been the focus of this research whereby the acquisition of science process skills can be achieved during the teaching and learning of science by providing opportunities to inculcate science process skills in their lessons.

Acquiring science process skills is considered as "learning how to learn" because children learn how to learn by thinking critically and using information creatively and they continue to learn when making discriminating observations, organizing and analyzing facts or concepts, giving reasons for particular outcomes, evaluating and interpreting results, drawing justifiable conclusions and predicting what will happen if anything were to be changed (Martin et al., 2001).

Process skills describe the types of thinking and reasoning required. Process skills can be divided into two categories, basic and integrated process skills. In science, basic science process skills help children to expand their learning through experience. Children begin with simple ideas, and expand to form new and complex ideas. It is hoped that emphasis on science process skills helps children discover meaningful information and 
accumulate knowledge by constructing their understanding within and beyond the science classroom (Martin et al., 2001).

Science process skills are seen as a problem solving skill in which a problem is represented, a systematic process is carried out in order to arrive to solve the problem (Gagne et al., 1993). Science process skills are important to teaching ways of reaching knowledge. The students need the process skills both when doing scientific investigations and during their learning process (Harlen, 2000; Taconis, Ferguson-Hessler \& Broekkamp, 2000). Science process skills is also believed to be able to ensure that students have the meaningful learning experience because they help students to develop higher order thinking (Germann \& Aram, 1996; Lee et al., 2002).

According to Germann \& Aram (1996) the basic science process skills provide the intellectual groundwork in scientific enquiry. The basic process skills are the prerequisites to the integrated process skills. The integrated process skills are the terminal skills for solving problems or doing science experiments.

Many researchers have done studies investigating science process skills in science education internationally (Lazarowitz \& Huppert, 1993; Germann \& Aram, 1996; Harlen, 1999; Beaumont-Walters \& Soyibo, 2001; Huppert,Lomask \& Lazarowitz, 2002; Harrell \& Bailer, 2004; Monhardt \& Monhardt, 2006) and in Malaysia (Chan, 1986; Sarmini, 1986; Kamariah et al., 1996; and Zurida, 1998; Salbiah, 2000; Saat, 2004). Mostly focusing on the acquisition and performance of science process skills among students, its relation with other skills such as logical thinking, or with achievement.

Considering that teachers are the main source in educating individuals, it is inevitable that there is a need for current teachers and prospective teachers to acquire science process skills and ways of teaching it to students in a science class. One's professional knowledge which is informed by one's professional background, experience and perceptions can be seen from the teachers' behaviors. It is also possible that the form of assessment affects how science is being taught. This is the current scenario in Malaysia, where teachers feel pressured into getting good results for the school, forgetting teaching to learn but teaching to pass the exam.

Toh et al. (2006) suggests that people in the East is very dependent on teachers in learning. They believe that teachers should provide prescriptive instructions during practical sessions. He also reported that teachers in this region attach a great importance to close guidance of their students' activities.

There is evidence to suggest that despite the premium placed on the teaching of science process skills since long ago in Malaysia, there is a lack of studies published on the inculcation of science process skills of Malaysian students in science class. Though, several studies reported in Malaysia on the acquisition of only certain science process skills, and the findings were that it is between average to poor (Chan, 1986; Sarmini, 1986; Kamariah et al., 1996; Zurida, 1998) This gives the impression that the inculcation of science process skills does not happen in the process of teaching and learning of a science classroom and research done by Chan (1986), Sharifah \&Lewin (1993) and Zurida (1998) reported this. Some might argue why do we use inculcating instead of developing? Eventhough the outcome is the same but inculcating a skill is more direct to the person or situation involved and it is a continuous process. It might be done indirectly or directly in a lesson. Development of a skill is more as an overall process whereby we look at the situation and process as the big picture and action towards the development involves deep planning and implementation. Inculcating SPS during science class is important to ensure acquisition of the skills takes place and the process in continuous. Thus, the purpose of this study was to investigate whether the teaching approaches used in the teaching and learning process of a science class are able to provide the opportunity to inculcate science process skills and to identify which science process skills were inculcated (if any) during the lesson.

\section{Methodology}

The main focus of this study is to investigate whether opportunities to inculcate science process skills were present during the process of teaching and learning. Thus, a qualitative approach was used in order to identify which type of teaching approaches manage to provide opportunities to inculcate science process skill and whether these opportunities where in fact planned or was created indirectly. The qualitative approach was adopted to give insights and description how and when the science process skills were inculcated. This study was carried out in two Smart Schools in Malaysia. 24 students aged 14 years old and two science teachers were the samples of this study. A stratified sampling technique was used to identify the students. Students were given an adapted Test of Science Process Skills of the original developed by the Malaysian Curriculum Development Center (1998). Questions were modified to suit Form two students for their content and concept being tested. Students were ranked according to their achievement score from highest to the lowest. The students were then divided into three groups of high achievers (85\%-75\%), moderate (65\%-74\%) and low achievers (64\%-55\%.) Four students were selected from each group from these two schools. To ensure the samples selected have 
similar achievement level, they were selected according to score marks within the range stated.

The criteria for selecting the two teachers were, both teachers teach form two (age 14) students, had attended a 14 weeks Course in Teaching and Learning approach for Smart Schools. Both teachers had agreed to be observed, interviewed and their lesson materials to be examined and analyzed.

\section{Instrumentation and Procedure}

Two main methods of collecting data were through observation and interview. In this study, non-participative observation and participant-observation were carried out. Interchangeable role of the observer were done according to the situation and progress of the teaching and learning process. Observations were done using an observation protocol in line with the conceptual framework and aim of this study. The duration of the observation is two hours per week for four weeks for each school. The total amount of observation was 16 hours, eight hours of observations for each school. The topic observed for the whole 16 hours was 'The World Through Our Senses: Light and Sight'.

Interviews with teachers were formally carried out whereas for the students formal and informal interviews were carried out. Formal interviews were done after class, where the students were called one by one for 20-30 minutes, require the students to explain incidents that the researcher needs to know more. Informal interviews were conducted in the classroom, while the students were having their class activities. Mostly of the questions were probing questions to investigate their knowledge and reasoning skills pertaining the science process skills.

There were two science process skill (SPS) checklist used; a) teacher's SPS check list, and b) student's SPS check list. These checklists were developed by the researcher with reference to the competency continuum used by schools in Pennsylvania (Mechling et al., 1994) and adapted to suit the definition used in the Malaysian Science Curriculum for the Science Process Skills. These check list were used when analyzing the transcriptions of the observations of teachers and students.

\section{Results and Discussion}

The results will be discussed according to these three aspects; a) how far does inculcation of science process skills occur during the science class, b) how far does the approaches used manage to provide opportunities for the inculcation of science process skills during class, and c) science process skill demonstrated by students during science class

\subsection{How Far Does Inculcation of Science Process Skills Occur during the Science Class}

Results from the interviews with the teachers about their planning of the lessons, showed that both of them did not plan learning activities to inculcate science process skills. According to both of them, these skills will be acquired indirectly during the lesson whether the students are aware or otherwise. Nonetheless, when asked to explain why they did not plan to inculcate science process skills in their lesson, Teacher A answered that she herself did not fully understand science process skills because of the lack of exposure to it. She added that it is embedded in the curriculum, "... so we do not have to teach it explicitly, we just do what the curriculum suggested". Teacher B defended that since the curriculum did not identify specifically which skills to be acquired, the focus of the lesson is on the content. These statements confirmed what the researcher observed that the skills were not taught explicitly but rather were inculcated while doing the activities.

Through document analysis of the curriculum specific science process skills should be acquired by the students for every topic taught. Since teachers themselves fail to identify which science process skills to inculcate or teach, they can just hope that students will acquire which ever science process that they happen to do in the lesson. Table 1 showed the frequency and percentage inculcated indirectly through their lesson on the topic 'The World Through Our Senses: Light and Sight'. Even though the topic taught were the same but because of the approaches and activities were different, Teacher B in School 2 managed to inculcate ten skills compared to Teacher A in School 1 who managed to inculcate only eight skills. The frequency of each skill also is different between school 1 and 2 and this is due to the approaches and activities carried out during the lessons were different. Some of the skills were inculcated while the students were doing the activities, but some skills were inculcated through questioning. 
Table 1. Frequency and percentage of science process skills inculcated

\begin{tabular}{lcc}
\hline Science Process Skills & School 1 & School 2 \\
\hline Observation (OB) & $4(13.79 \%)$ & $5(9.43 \%)$ \\
Classification(CS) & $2(6.90 \%)$ & $1(1.89 \%)$ \\
Measurement and use of number(MN) & $2(6.90 \%)$ & $2(3.77 \%)$ \\
Making Inference(MI) & $2(6.90 \%)$ & $3(5.67 \%)$ \\
Making Prediction(MP) & $2(6.90 \%)$ & $1(1.89 \%)$ \\
Communications(CM) & $13(44.83 \%)$ & $13(24.53 \%)$ \\
Using time and space(UTM) & $0(0.00 \%)$ & $0(0.00 \%)$ \\
Interpreting data(ID) & $1(3.44 \%)$ & $5(9.43 \%)$ \\
Defining Operationally(DO) & $0(0.00 \%)$ & $0(0.00 \%)$ \\
Controlling Variables(CV) & $0(0.00 \%)$ & $5(9.43 \%)$ \\
Forming Hypothesis(FH) & $0(0.00 \%)$ & $6(11.32 \%)$ \\
Experimenting(EX) & $3(10.34 \%)$ & $12(22.64 \%)$ \\
Total & $\mathbf{2 9}(\mathbf{1 0 0} \%)$ & $\mathbf{5 3 ( 1 0 0 \% )}$ \\
\hline
\end{tabular}

Table 2 is the comparison of the science process skills that were inculcated with what should be inculcated in class. From the analysis of the curriculum, it was found that there are only eleven SPS that should be inculcated in the topic. Before planning the lesson, teachers should identify which SPS that should be inculcated. But this was not happening. Without planning to inculcate the specific SPS, teachers could not determin which science process skills will be acquired by the students. Both of the teachers failed to inculcate all eleven science process skills identified in the curriculum to be inculcated during the lesson. When asked further if they feel guilty if by not planning to teach or inculcate these skills the students would not be able to acquire them, they said that they do but they compensate by saying that sooner or later all twelve science process skills will be acquired by the students by the end of the year. They also added that the main focus is to be able to understand the concepts and facts in the lesson for them to pass the examination.

When told that some of the skills needed to be inculcated or taught explicitly especially making inferences, making predictions, forming hypothesis and defining operationally for the students to acquire them, they seemed quiet uneasy and was quick to agree and willing to give it a try for the next lesson. Despite all these, the teachers do feel that science process skills are important to be acquired by students to understand more of the concept taught but because of time constraint and workload, they feel it is troublesome to identify and then plan to inculcate them. They feel it would make their life easier and are willing to plan to teach these skills if it is specified in the curriculum clearly. They also feel that they need to be exposed on how to assess science process skills in class and how to make sure it is inculcated in a science class.

Table 2. Comparison of science process skills inculcated with SPS in the curriculum

\begin{tabular}{lccc}
\hline Science Process Skills & School 1 & School 2 & SPS in Curriculum \\
\hline Observation (OB) & $\sqrt{ }$ & $\sqrt{ }$ & $\sqrt{ }$ \\
Classification(CS) & $\sqrt{ }$ & $\sqrt{ }$ & $\sqrt{ }$ \\
Measurement and use of number(MN) & & & $\sqrt{ }$ \\
Making Inference(MI) & $\sqrt{ }$ & $\sqrt{ }$ & $\sqrt{ }$ \\
Making Prediction(MP) & $\sqrt{ }$ & $\sqrt{ }$ & $\sqrt{ }$ \\
Communications(CM) & $\sqrt{ }$ & $\sqrt{ }$ & $\sqrt{ }$ \\
Using time and space(UTM) & $\sqrt{ }$ & $\sqrt{ }$ & $\mathrm{X}$ \\
Interpreting data(ID) & $\mathrm{X}$ & $\mathrm{X}$ & $\sqrt{ }$ \\
Defining Operationally(DO) & $\sqrt{ }$ & $\sqrt{ }$ & $\sqrt{ }$ \\
Controlling Variables(CV) & $\mathrm{X}$ & $\mathrm{X}$ & $\sqrt{ }$ \\
Forming Hypothesis(FH) & $\mathrm{X}$ & $\sqrt{ }$ & $\sqrt{ }$ \\
Experimenting(EX) & $\mathrm{X}$ & $\sqrt{ }$ & $\sqrt{ }$ \\
& $\mathrm{X}$ & $\sqrt{ }$ & \\
\hline
\end{tabular}




\subsection{How Far Does the Approaches Used Manage to Provide Opportunities to Inculcate Science Process Skills during Class}

The findings showed that inculcation of science process skills did indeed occur during teaching and learning process in a science classroom through the teaching approach used by the teachers, activities done by students and the teaching materials used in the lesson. Table 3 shows the frequencies teachers using the teaching approaches throughout 8 science lessons for the two schools. Percentage of the usage is in parentheses. Results showed that teachers used more than one teaching strategies or approaches throughout the lessons. The approaches used were discussions, exploring students' ideas, open laboratory inquiries, lectures and student presentations. The use of different approaches manages to provide opportunities to inculcate science process skills indirectly or directly.

Table 3. Comparison of teaching approaches used during 8 science lessons

\begin{tabular}{lll}
\hline Teaching Approaches & School 1 & School 2 \\
\hline Discussion & $18(39.13 \%)$ & $20(39.21 \%)$ \\
Exploration of Ideas & $6(13.04 \%)$ & $8(15.69 \%)$ \\
Open Laboratory Inquiry & $11(23.91 \%)$ & $13(25.50 \%)$ \\
Lecture & $10(21.75 \%)$ & $8(15.69 \%)$ \\
Student's presentation & $1(2.17 \%)$ & $2(3.91 \%)$ \\
Total & $\mathbf{4 6 ( 1 0 0 \% )}$ & $\mathbf{5 1}(\mathbf{1 0 0 \% )}$ \\
\hline
\end{tabular}

Results also showed that strategy incorporating discussion manage to inculcate most type of science process skills. Discussions were found to be able to inculcate five basic skills and four integrated science process skills. The basic science process skills inculcated were observation (OB), classifying (CS), making inference (MI), making prediction (MP) and communication (CM). Between the five skills, communication skills (CM) were the most being inculcated, followed by observation skills (OB). Integrated science process skill inculcated were data interpretation (ID), controlling variables (CV), forming hypothesis (FH) and experimenting (EX). Between the four skills, interpretation of data was the most being inculcated. Table 4 showed science process skills that are inculcated according to teaching approaches used. Numbers in parentheses beside the code for science process skills represents frequencies of it being inculcated.

Table 4. Science process skills inculcated according to teaching approaches

\begin{tabular}{lll}
\hline Teaching Approach & School 1 & School 2 \\
\hline Discussion & $\mathrm{OB}(7), \mathrm{CS}(2), \mathrm{MI}(1), \mathrm{MP}(6)$, & $\mathrm{OB}(6), \mathrm{CS}(1), \mathrm{MI}(5), \mathrm{MP}(1), \mathrm{CM}(2)$, \\
& $\mathrm{CM}(18), \mathrm{ID}(3), \mathrm{FH}(2), \mathrm{EX}(1)$ & $\mathrm{ID}(4), \mathrm{CV}(3), \mathrm{FH}(1), \mathrm{EX}(1)$ \\
Exploration of Ideas & $\mathrm{OB}(2), \mathrm{MI}(6), \mathrm{CM}(4), \mathrm{ID}(3)$, & $\mathrm{OB}(3), \mathrm{MN}(1), \mathrm{MI}(4), \mathrm{CM}(3)$, \\
& $\mathrm{DO}(2), \mathrm{CV}(3), \mathrm{FH}(1)$ & $\mathrm{ID}(2), \mathrm{FH}(7)$ \\
Open Laboratory Inquiry & $\mathrm{OB}(3), \mathrm{MN}(5), \mathrm{MI}(1), \mathrm{CM}(3)$, & $\mathrm{OB}(5), \mathrm{MN}(8), \mathrm{CM}(2), \mathrm{CV}(10)$, \\
& $\mathrm{EX}(11)$ & $\mathrm{FH}(1), \mathrm{EX}(16)$ \\
Lecture & 0 & 0 \\
Student's Presentation & $\mathrm{CM}(5)$ & $\mathrm{MN}(5), \mathrm{CM}(5), \mathrm{ID}(4)$ \\
\hline
\end{tabular}

When asked, Teacher A responded that she used the discussions method to discuss the results of an experiment in order to rectify or add on facts or information collected by the students. This activity she hoped will enhance the students' understanding. Teacher B said through discussions, students will be able to interact with each other, and this will in turn boost their confidence. She added that students like to discuss to confirm their understanding rather than being told about the facts. Discussions also were carried during student's presentation, where after the presentation, students will pose questions for the presenters to answer and wherever needed the teacher will intervene to confirm or rectify or to explain further the problems discussed. Below is an example of a student's 
presentation taking place, Izah is a member of Group 1. She is presenting that light moves straight.

Izah: Shadows happen when light cannot go through an object and the light will be stopped by the object.

Ali: Why is the shadow black?

Ati: Because light cannot go through opaque object.

Ragu: Why is it shadows sometimes is bigger or taller that us?

Teacher A: Anyone?

Najman: The size of the shadows depend on the distance of the object with the source of light.

Teacher A: Good, other than the distance, the angle where the source of light shoot also affect the size of the object.

Izah displayed the skills of communicating (CM) by representing facts with her own words, followed by Najman giving explanations on what affect size of shadows, he demonstrated the skill of making inferences (MI). Discussions were also carried out to discuss the results of an experiment as shown in the example below:

\section{Teacher B asked every group to give the results and she wrote it on the black bored. She asked students to present their results in a form of a table for experiment 2 and 3. They have done an experiment on Sound and Hearing.}

Teacher : Why was the ringing sound gradually die out?

Ali : well.. I think at first there is air in the tank and then when the air was suck out slowly so did the sound.

By presenting the results in a table, the teacher indirectly inculcated the communication skill(CM) and Ali showed the skill of making inferences (MI) when he tried to give reasons why the ringing sound died out. The observations showed that activities involving discussion manage to provide opportunities to inculcate science process skills in a science class. At the same time it also built confidence in students to ask questions and giving answers in their own words.

Exploration of ideas requires teacher to prepare related questions. Teacher A used this approach more frequent than Teacher B. When asked if Teacher A prepared a set of questions prior to the lesson, she said 'no', but it came up during the discussion. It was spontaneous and it was natural for her because she has a lot of experience teaching this topic, and the issues that came out were almost the same. Teacher B also said that she did not prepare prior to the lesson but also it came naturally during the discussions. She added sometimes the questions came up after seeing the students' reaction and she saw the need to explore more and to assess their understanding. Basic science process skills that were inculcated using this approach were observation skills (OB), measurement and use of number (MN), making inferences (MI) and communication skills (CM). Making inferences skill were the most being inculcated through this approach. While skill to control variable $(\mathrm{CV})$ is the skill most being inculcated among the integrated science process skills.

In the open laboratory inquiry approach, students were allowed to do their experiments on their own using the lab sheet as their guide. The students made their own decision on how to plan, execute and record the results. This approach managed to provide opportunities to inculcate the most basic science process skills (measurement and use of number skill (MN)) and integrated science process skills (experimenting (EX)).

\subsection{Science Process Skill Demonstrated by Students during Science Class}

Acquisition of science process skills was demonstrated by students in both schools. They differ in the intensity of acquisition of type of science process skills. These are dependent on the teaching approaches and activities carried out. The level of the skills was also analyzed through the transcription of the observation and informal interviews and test answers. Table 5 showed the frequencies of all the eleven skills that were demonstrated by students during science lessons. 
Table 5. Frequencies of observation skills demonstrated during science lessons

\begin{tabular}{lcc}
\hline \multicolumn{1}{c}{ Science Process Skills } & School 1 Frequencies(\%) & School 2 Frequencies(\%) \\
\hline Observation (OB) & $10(12.20 \%)$ & $13(13.54 \%)$ \\
Classifying (CS) & $3(3.66 \%)$ & $1(1.04 \%)$ \\
Measuring and using numbers (MN) & $6(7.32 \%)$ & $16(16.67 \%)$ \\
Making inferences (MI) & $7(8.54 \%)$ & $5(5.21 \%)$ \\
Making prediction (MP) & $2(2.44 \%)$ & $1(1.04 \%)$ \\
Communication (CM) & $18(21.95 \%)$ & $15(15.63 \%)$ \\
Interpreting data (ID) & $7(8.54 \%)$ & $11(11.46 \%)$ \\
Defining Operationally (DO) & $2(2.44 \%)$ & $0(0.00 \%)$ \\
Controlling variables (CV) & $9(10.98 \%)$ & $12(12.50 \%)$ \\
Forming hypothesis (FH) & $1(1.22 \%)$ & $3(3.13 \%)$ \\
Experimenting (EX) & $17(20.73 \%)$ & $19(19.79 \%)$ \\
Total & $82(100 \%)$ & $96(100 \%)$ \\
\hline
\end{tabular}

There are three types of observation skills; Type 1, using various senses to identify similarities and differences, Type 2, identify changes, and Type 3, observe using measurement. The acquisition of these skills was assessed during the teaching and learning process throughout the 16 science lesson being observed. Students demonstrated Type 1 observation skill (60.9\%) most during lesson compared to Type 2 (21.7\%) and Type 3 (17.4\%). Observation skill type 1 are occurring more compared to type 2 and 3 . Type 1 and 2 are qualitative observation skill whereas type 3 is a quantitative observation skill. For this skill to be inculcated, activities should be planned and using suitable teaching approach. By doing this the opportunity to acquire this skill was provided.

Classification skill includes action to group/categories/class according to specific characteristics. It also includes the ability to determine what kind or types of characteristic to group materials. Classification skills were found to be less inculcated and when it was brought up in the interviews with the teachers, they say it is true because the topic does not require them to do a lot of classifying. Nonetheless, the opportunity to inculcate this skill was still present when they were asked to classify animals into any category they feel suitable. The level of acquisition was also identified through the way these students classify them. They are classified as having acquired high level of classification if they manage to get three layer or more categories, moderate if they can classify only two layer and low if they can only come up with one layer.

Measuring and using numbers skill require students to measure using measuring instrument, get answers using formulas or do calculation. Students from both school showed moderate skill using measurement tools and a few of them was not very sure how to measure using a protractor and even some of them do not know what to measure. From the observation, students were able to do the experiment, the teacher helps them with the apparatus especially the power source. The teacher did not manage to help those who did not know how to measure using a protractor. From the observation, however, this skill is more towards students using the apparatus and reading the measurement using the right unit of measure. The Teacher has to create opportunities for students to acquire this skill in their science lesson by choosing suitable teaching methods and activities. This skill is best acquired by guided activities and facilitation by the teacher.

Making inferences skill includes the action of using the observed information to interpret, or make an early conclusion. This conclusion might be right and might be wrong. From the observation, it was found that this skill was only inculcated whenever the teacher asked the student to give reasons to their experiment's results. The teacher did not use the term 'inference' when asking students to give their reasons. Thus, the students did not realize that there were making inferences.

Making prediction includes action of using evidence from the past or present to predict what might happen and using pattern as evidence for forecasting. Findings showed that this skill were only inculcated when the teacher asked question for the students to make prediction. Both teacher asked students to predict what happen when given a situation without realizing that it is one of the process skills. They admit that they asked those questions just as an induction to the topic that day. This skill was inculcated indirectly in class. To make sure that this skill 
does not get left out teacher will have to create the opportunity for students to acquire them. It is a guided process where teachers will have to ask questions or posed problem solving questions for the students to make predictions.

There are five actions that represent communication skill. Among the five actions for communication skill, action requiring the students to talk, listen and explain their ideas to the audience was the most frequent happening in class. It was found mostly while the students were discussing, or when questions arose while doing task or experiments and while presenting their task. This skill can be inculcated whether it is guided or not. But to make sure that it is inculcated; students should be given opportunity in class to demonstrate this skill.

Two most frequent actions of interpreting data that were demonstrated in class were stating the relationship between variables and making suitable conclusion using the information and data they have. This skill is a continuity of the skill of making inferences and it is one of the integrated science process skills. This skill would not be acquired without proper planning and guidance from the teacher. Opportunity should be created while teaching and doing activities.

From the observations, it was found that the skill to define operationally did not emerge during the class session. It emerged when the researcher took the participant-observer role as a facilitator to investigate whether the students were able to acquire this skill when given the opportunity. The findings showed that this skill will only be inculcated and acquired if students were asked to give the definition operationally. This skill is found to be most difficult because students found it hard to relate the definition with the experiment that they had done. Through guided and exploring questions posed by the researcher the students were able to come up with a statement of defining operationally. But if given the chance on their own the researcher found it doubtful if they will be able to acquire this skill at all.

Controlling variables skill was found to emerge before and during the experiment. The findings revealed that in School 1, this skill was not inculcated explicitly but in School 2, Teacher B purposely asked the students to identify the variables involved before doing the experiment. When asked why she did that, she said it was important to teach this skill explicitly so that the students are aware of the variables and would always make it a point to identify the variables before doing experiments. For Teacher A, she said the student will acquire this skill indirectly while doing the experiment and during discussion. And from the observation in School 1, this skill emerged while the students were doing the experiment. But from the informal interview with the students, the study found that the students were not aware which variables were manipulated and which were kept constant. They were not aware of the importance of identifying the variables and its implication when they want to make the conclusion to experiment.

Forming hypothesis also requires teacher to ask students to make hypothesis, it cannot be acquired indirectly. From the observation, both teachers asked the students what were their hypothesis to the experiment. The students were able to answer them because it is already in the lab sheet. When asked if the teachers feel if it's important for students to form their own hypothesis, they feel there is no need to do so, because all of the experiment already comes with the hypothesis to be tested.

The experimenting skill was found most inculcated in the classroom. This might be because of the topics taught that have several experiment activities. The findings showed that mostly all the students acquired this skill, and mostly were because they followed the procedure in the lab sheet directly and systematically. But the one thing that I found most interesting was that there was a group of students who did the 'fair testing' procedure to confirm their results. This was done by students in both schools. When asked why they did the 'fair test' exercise they said to make sure that the result is right.

\section{Conclusion}

This study implied that teaching approaches used in a science class can provide opportunity to inculcate science process skills. These skills need to be realized by teachers that it is important in the learning of science and it serve as a scaffold to other cognitive skills such as logical thinking, reasoning and problem solving skills. It is especially important that instruction to the task is clear and useful. Students should be aware the science process skills that were to be acquired and they should be guided through exploration questioning. This implied that teachers should always give guidance throughout the experiment or lesson in order for the students to realize they are actually learning to acquire the science process skills. This are supported by strong evidence from well-designed, controlled experimental studies which supports direct instructional guidance (Moreno, 2004). Hardiman, Pollatsek, and Weil (1986) and Brown and Campione (1994) supported that when students learn science in classrooms with pure-discovery methods and minimal feedback, they often become lost and frustrated, and their confusion can lead to misconceptions. This study showed that even though teachers do not purposely 
plan to inculcate science process skills in their lesson, it was found that the opportunity to inculcate science process skills through the activities were provided. Learning science is seen by many as meaningful if skills or knowledge is acquired in a constructivist approach, learning environment should be planned so that the learning and acquisition can be achieved. This study proved that skills which is abstract should be developed through the teacher's facilitating ability while teaching using any kind of approaches. Children should not be left on their own and hoped to be able to acquire certain skills without any intervention from the teacher. As Aulls (2002) observed in her research that the 'scaffolding method were not effective because students failed to make learning progress in a discovery setting.

Approaches in teaching usually involve activities which are students centered. Thus, the discussion approach managed to inculcate the most science process skills and from the figure it showed that all types of teaching approaches incorporate discussion making it the most suitable teaching approach to use to provide opportunities for the inculcation of science process skills. But two skills were not able to be inculcated which were measurement and using of numbers and defining operationally. These two skills need to be taught explicitly and plan to be taught in class and cannot be acquired implicitly. Thus, it is important that teachers make it a point to that the discussion activities should be planned and given guidance to inculcate these two skills.

The process of teaching and learning science that uses various teaching approaches in one science lessons has extra advantages in terms of providing opportunities for the inculcation of science process skills. It also manage to provide the students the opportunity to learn independently and throughout all the activities in class, the student manage to acquire at least some of the skills. The use of various teaching approaches is in juxtaposition to each other, for instance when the teacher uses the discussion, he or she needs to ask question to explore students' ideas and stimulate their thinking while doing the activities. Similarly, the use of open laboratory inquiry, discussions among students, students with teachers and exploration questions also takes place. Science teaching and learning process is a dynamic process, where the movement from one teaching approach to another occurs. It also not necessarily always occur in an orderly sequence. The use of various teaching approaches in a single lesson can create more opportunities for inculcation and acquisition of science process skills in the classroom. Figure 1 shows a representation of the inculcation of science process skills according to the intensity of it being inculcated formed from the results of this study.

This study also implies that without proper planning and guidance, the opportunity to inculcate, thus mastery or even acquisition of science process skills might not occur. If teachers take the attitude that the students will get it eventually in a science class, the goal of science education might not be achieved. Science teaching should be plan and taught along side with the aim of inculcating science process skills to ensure the acquisition of these skills among students.
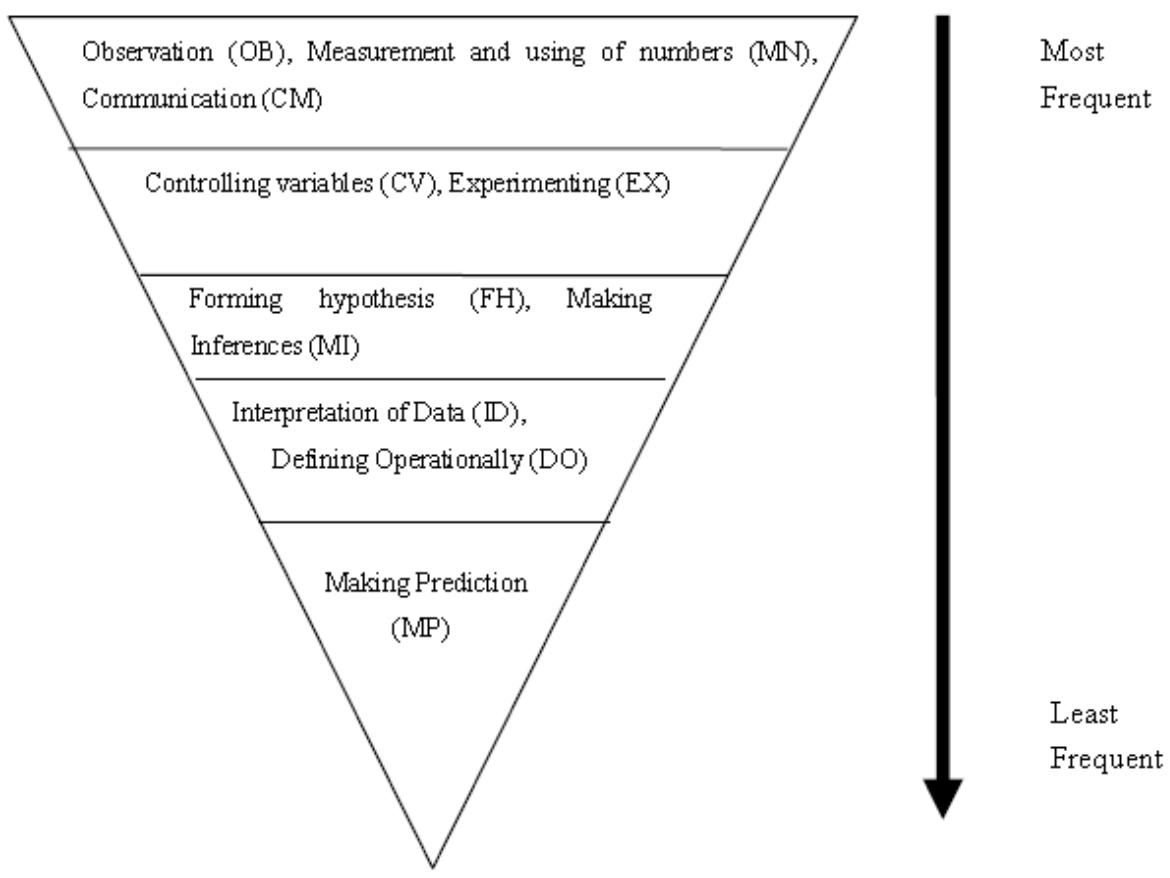

Figure 1. Science process skills inculcated according to intensity 


\section{References}

Aulls, M. W. (2002). The contributions of co-occurring forms of classroom discourse and academic activities to curriculum events and instruction. Journal of Educational Psychology, 94, 520-538. http://dx.doi.org/10.1037/0022-0663.94.3.520

Bakar, K. A., Tarmizi, R. A., \& Isa, A. M. M. (1996). Pengukuran Saintifik Di Kalangan Pelajar Lepasan SPM. Paper presented at Seminar Kebangsaan Penilaian Program KBSM: Isu dan Hala Tuju Strategik Ke Arah Abad 21. Institut Aminuddin Baki. 2-6 September.

Beaumont-Walters, Y., \& Soyibo, K. (2001). An analysis of high school students' performance on five integrated science process skills. Research in Science and Technological Education, 19(2), 133-145. http://dx.doi.org/10.1080/02635140120087687

Gagne, E. D., Yekovich, C. W., \& Yekovich, F. R. (1993). The cognitive psychology of school learning. New York: Harper Collins College Publishers.

Germann, P. J., \& Aram, R. J. (1996). Student performances on the science processes of recording data, analyzing data, drawing conclusions, and providing evidence. Journal of Research in Science Teaching, 33(7), 773-798. http://dx.doi.org/10.1002/(SICI)1098-2736(199609)33:7<773::AID-TEA5>3.0.CO;2-K

Gim, C. S. (1984). Acquisition of science process skills among Form IV students in Kota Bharu. Tesis Sarjana. Universiti Malaya.

Hardiman, P., Pollatsek, A., \& Weil, A. (1986). Learning to understand the balance beam. Cognition and Instruction, 3, 1-30. http://dx.doi.org/10.1207/s1532690xci0301_3

Harlen, W. (1999). Purpose and procedures for assessing science process skills. Assessment in Education: principles, policy \& practice, 6(1), 129-144. http://dx.doi.org/10.1080/09695949993044

Harlen, W. (2000). Teaching, learning and assessing science process skills. Assessment in Education, 6(1), 129-144. http://dx.doi.org/10.1080/09695949993044

Harrell, P. E., \& Bailer, J. (2004). Pass the mealworms, please: Using mealworms to develop science process skills. Science Activities, 41(2), 33-36. http://dx.doi.org/10.3200/SATS.41.2.31-36

Huppert, J., Lomask, S. M., \& Lazarowitz, R. (2002). Computer simulations in the high school: students' cognitive stages, science process skills and academic achievement in microbiology. International Journal of Science Education, 24(8), 803-821. http://dx.doi.org/10.1080/09500690110049150

Ismail, Z. (1998). Penguasaan kemahiran proses sains pelajar sekolah rendah dan menengah. Jurnal Kurikulum Pusat Perkembangan Kurikulum, 1(1), 109-120.

Kirschner, P. A., Sweller, J., \& Clark, R. E. (2006). Why minimal guidance during instruction does not work: An analysis of the failure of constructivist, discovery, problem-based, experiential and inquiry-based teaching. Educational Psychologist, 41(2), 75-86. http://dx.doi.org/10.1207/s15326985ep4102_1

Lazarowitz, R., \& Huppert, J. (1993). Science process skills of 10th grade biology students in a computer-assissted learning setting. Journal of Research on Computing in Education, 25(3), 367-382.

Lee, A. T., Hairston, R. V., Thames, R., Lawrence, T., \& Herron, D. S. (2002). Using a computer simulation to teach science process skills to college biology and elementary majors. Computer Simulations Bioscene, 28(4), 35-42. http://dx.doi.org/10.1081/SAC-120002714

Martin, R. E., Sexton, C., Franklin, T., \& McElroy, D. (2001). Teaching science for all children (3rd ed.). Massechusetts: Allyn \& Bacon.

Mechling, K., Bires, N., Kepler, L., Oliver, D., \& Smith, B. (1994). A Recommended Science Compentency Continuum for Grades K-12 for Pennsylvania Schools. Pennsylvania: Department of Education.

Monhardt, L., \& Monhardt, R. (2006). Creating a context for the learning of science process skills through $\begin{array}{lllll}\text { picture books. Early Childhod Education Journal, } & \text { 34(1), }\end{array}$ http://dx.doi.org/10.1007/s10643-006-0108-9

Moreno, R. (2004). Decreasing cognitive load in novice students: Effects of explanatory versus corrective feedback in discovery-based multimedia. Instructional Science, 32, 99-113. http://dx.doi.org/10.1023/B:TRUC.0000021811.66966.1d

Saat, R. M. (2004). The acquisition of integrated science process skills in a web-based learning environment. Research in Science \& Technological Education, 22(1), 23-40. 
http://dx.doi.org/10.1080/0263514042000187520

Som, S. M. (2000). Kajian kes tentang pelaksanaan kemahiran proses sains dalam pengajaran dan pembelajaran biologi tingkatan empat. Unpublished Masters Thesis, Universiti Kebangsaan Malaysia.

Taconis, R., Ferguson-Hessler, M. G. M., \& Broekkamp, H. (2000). Teaching science problem solving: An overview of experimental work. Journal of Research in Science Teaching, 38, 442-468. http://dx.doi.org/10.1002/tea.1013

Theeran, S. B. (1986). Kajian Kemahiran-kemahiran Proses Sains Bersepadu bagi pelajar-pelajar di sekolah menengah Daerah Kelang dan Kuala Langat, Selangor. Unpublished Bachelor Thesis. Universiti Teknologi Malaysia.

Toh, K. A., Ho, B. T., Wan, Y. K., \& Ang, D. (2006). Science teachers' perceptions: similarities and differences in the U.S., England, Singapore and Japan. Asia Pacific Journal of Education, 24(1), 1-11.

Zin, S. M. S., \& Lewin, K. M. (1993). Insights into Science Education: Planning and Policies in Malaysia. Paris: UNESCO. 